\title{
5S ELEMENTS AS STEPS TO BRIDGE THE GAP IN TRANSMITTER MANUFACTURING PROCESS
}

\author{
UDC: 621.317 \\ 658.5 \\ Original Scientific Paper \\ Miloš VORKAPIĆ ${ }^{1}$, Srđan BOGETIĆ ${ }^{2}$, Dragoljub TANOVIĆ ${ }^{3}$, \\ Mohammad Sakib HASAN ${ }^{4}$, Aleksandar KOVAČEVIĆ ${ }^{3}$ \\ ${ }^{1}$ University of Belgrade, Institute of Chemistry, Technology and Metallurgy - Centre for Microelectronic \\ Technology, 11000 Belgrade, Njegoševa 12, Republic of Serbia \\ E-mail: worcky@nanosys.ihtm.bg.ac.rs \\ ${ }^{2}$ Belgrade Business Academy for Applied Studies, 11000 Belgrade, Kraljice Marije 73, Republic of Serbia \\ ${ }^{3}$ University of Belgrade, Faculty of Mechanical Engineering, 11000 Belgrade, Kraljice Marije 16, \\ Republic of Serbia \\ ${ }^{4}$ People's Republic of Bangladesh
}

Paper received: 19.11.2019.; Paper accepted: 11.12.2019.

\begin{abstract}
In this paper, GAP analysis and $5 \mathrm{~S}$ tool are applied in the case of realization of a compact pressure transmitter. GAP analysis, combined with the $5 \mathrm{~S}$ tool, can qualitatively indicate the critical points in the manufacturing, assembly and quality control of a finished transmitter. Existing errors lead to the appearance of possible risks in the realization of production processes, from the input of raw materials to the assembly of the finished product. In order to eliminate the existing errors, the main steps of the GAP analysis are described in detail. Guidelines are provided on how to improve the workplace manufacturing process through certain improvements by applying all $5 \mathrm{~S}$ elements. According to the implemented action plan, the main causes of risk occurrence in the GAP analysis were: human factor and processing technologies. The human factor was characterized by poor control in the workplace (there is no discipline), poor training and incompetence of employees for the given tasks. Processing technology involves obsolete machines, which can introduce deviations of dimensions and tolerances from the prescribed values.
\end{abstract}

Keywords: GAP Analysis; 5S; Risk; Manufacturing process; Transmitter; Improvement.

\section{INTRODUCTION}

GAP analysis can give a good indication of the current state of the company through the implementation of $5 \mathrm{~S}$ tools. In this paper manufacturing process, assembling and control of the finished compact pressure transmitter (CPT) will be analyzed. Occurrence of gaps beyond the acceptable tolerances can be considered as errors, from semifinished to finished products. Risk consideration, through GAP analysis and implementation of $5 \mathrm{~S}$ tools, enables an organization to take some steps in accepting or reducing risks.

GAP analysis is an effective tool in raising the level of product performance, process and organization of a business. The 5S tools in GAP analysis are helpful for identification of critical places and making the workflow more functional, with as little waste as possible. Recorded big gaps can be characterized as errors. These errors can be repeated over time, and they can become risk elements that affect the final control and assembly of the transmitter.

In this paper, the the application of GAP analysis through the implementation of $5 \mathrm{~S}$ tools is demonstrated by using the production workflow of a compact pressure transmitter (CPT) (from the domestic manufacturer ICTM-CMT) as an example. Generally, the CPT consists of two modules: 1) a sensor block with a fixing element, and 2) an enclosure containing an electronic signal 
processing unit and a connector. Errors (i.e. elements of potential risks) were identified through the fabrication and assembly of these modules.

The benefits of using $5 \mathrm{~S}$ tools in a company are related to:

- Quality - Constant visual control is performed, so minor errors are also reported;

- Equipment performance - Routine cleaning of machines and tools is carried out, inspection activities are carried out to prevent sudden and unplanned failures;

- Productivity - Waste is reduced and workplacedefined procedures are followed;

- Safety - Danger and risk exposure in the workplace are reduced. Procedures for storing and organizing tools and accessories are followed.

GAP analysis offers important steps in removing the gap, based on error occurence. If these errors remain unremoved, potential risks can appear, (Vorkapić et al., 2019). In order to eliminate the existing errors, the main steps of the GAP analysis are analyzed in detail in this paper, and guidelines are also given on how to ameliorate the process through certain improvements in the quality of workmanship of the individual elements.

Risk, by definition, represents a certain level of probability (or uncertainty) with respect to desired outcomes (Edmund and Patricia, 1997). The paper analyzes the notion of "technical risk" arising within a design or technology (Miller and Lessard, 2001). Technical risk by its nature should be carefully evaluated when making decisions in project tasks (Mishalska, 2006). According to the same source, by considering technical risk, processes are improved in accordance with the procedures described and the cost of defective products (repairs, guarantees, and additional services) is reduced.

According to Kliem (2000), today, technical risk is increasingly being given attention which means: 1) impossibility to determine the relation between key processes; 2) lack of access to technical expertise; 3) lack of agreement for analysis, design tools and techniques of projections; 4) lack of knowledge about technology application; 5) choosing the wrong technology; 6) limitation in the application of existing computer technology.
A large number of errors occur in the early stages of product technology development and design. A progressive increase in the overall cost of product will follow if errors are not detected and eliminated at this stage. Williams (1995) indicates that the failures of major engineering projects lead to serious damages that may result from not considering the risk. Miller and Lessard (2001) emphasized that understanding and managing risks is a challenging task for early stage designers.

Tollei et al. (2000) have identified a number of risk factors, concerning design and documentation, such as, for example: 1) design problems, 2) lack of design verification, 3) problems with deadlines, 4) inadequate and unqualified design team of people, 5) short time for fast market demands.

\section{GAP analysis}

GAP analysis is a tool that helps businesses to determine where they want to be, and find the gap between where they are now and where they would like to be (Awasthi et al., 2018).

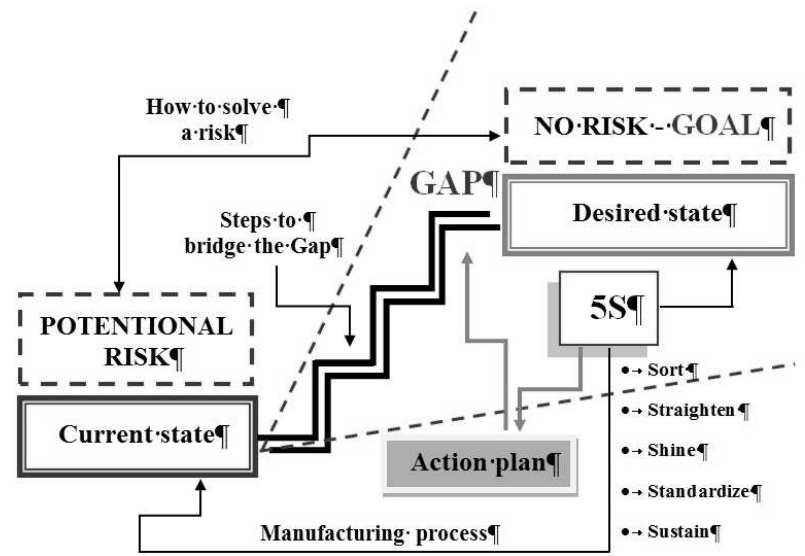

Figure 1: Schematic representation of the GAP analysis with $5 S$ tool

Figure 1 shows the path that bridges the gap (or potential risk) through the implementation of the $5 \mathrm{~S}$ tool. Finally, an action plan is drafted, outlining the exact actions that must be taken to eliminate the gap.

According to Davis et al. (2002), Tsai et al. (2011), Marra et al. (2018), the process of the GAP analysis is consisted of five steps:

1. Describing the area of activity - Different areas of activity that should be analyzed and improved are being described, as in Table 1 . The analysis can be quantitative and qualitative. In the report about the GAP analysis there 
should be a column named „future state”. Apart from the current state, the future one points out to the defined goals which the enterprise wants to achieve.

2. Identifying areas of improvement - Here, specific areas of improvement are being identified, within the area of activity stated in the step 1.

3. Setting goals - This step represents setting goals for each area. These goals should be realistic and achievable in the defined timeframe.

4. Analyzing the current state - The current state of the enterprise should be analyzed, before creating a realistic action plan. It is being considered whether the enterprise is making impovement towards the desired state. Exactly between this and the next step is where the gap occurs.

5. Bridging the gap - Steps for improvement are being described here, as well as the action plan in order to reach the desired state. One of the ways to do that is determining the most critical gaps, i.e. realizing what are the things preventing the enterprise from reaching its goals, while defining the risky spots at the same time.

Table 1: Steps in the GAP Analysis Process

\begin{tabular}{|l|l|l|}
\hline \multicolumn{1}{|c|}{ Entrance } & \multicolumn{1}{|c|}{ Activities } & \multicolumn{1}{c|}{ Exit } \\
\hline Area of activity & $\begin{array}{l}\text { - The area is analyzed from a broad } \\
\text { to a narrower context. }\end{array}$ & $\begin{array}{l}\text { - Report on the current and future state, } \\
\text { or recommendations on the future } \\
\text { (desired) state. }\end{array}$ \\
\hline $\begin{array}{l}\text { Identification of specific } \\
\text { places }\end{array}$ & $\begin{array}{l}\text { - Specific locations for } \\
\text { improvement are identified. }\end{array}$ & $\begin{array}{l}\text { - List of specific places where errors or } \\
\text { potential risks may occur. } \\
\text { - Checklist. } \\
\text { - Improvement measures are given.. }\end{array}$ \\
\hline Goals & $\begin{array}{l}\text { - Defining goals for eliminating } \\
\text { errors or potential risks within a } \\
\text { defined time. }\end{array}$ & $\begin{array}{l}\text { - List of goals and deadlines for } \\
\text { removing errors by defined specific } \\
\text { place. }\end{array}$ \\
\hline Current state & $\begin{array}{l}\text { In compared to other competitors, } \\
\text { areas with poorer performance } \\
\text { are revealed. }\end{array}$ & $\begin{array}{l}\text { - Recommendations for improving a } \\
\text { process, product, or organization. }\end{array}$ \\
\hline Bridging the gap & $\begin{array}{l}\text { The order of the steps for } \\
\text { improvement is written. }\end{array}$ & $\begin{array}{l}\text { - An action plan outlining all possible } \\
\text { solutions to reduce the gap }\end{array}$ \\
\hline
\end{tabular}

During the finalization and the assembly of the product, certain number of errors are inevitable, which is an indicator of potential risks. This number is mostly generated during the production process. In the Table 2, there is an example of the report describing the current state and giving directions for the future.

According to Mogos et al. (2019), the GAP analysis can be useful in analyzing the process approach which includes: reducing costs, shortening the activity duration, more efficient use of resources, consistent and predictable results, as well as focusing on the possibility of improving. The control list is the starting point in identifying potential risky spots. Such risks have the biggest influence on productivity, performances, quality and the cost-effectiveness of the production process.

In the Table 3, there is an example of the control list. In case it is determined that the risky event exists (1), it implies that, in the description of the risky event (2), it should be stated what the risk (gap) is, as well as which are the factors (3) causing it. In the column (4), clear and objective reasons are being listed, together with specific terms.

In the column (3) of conditional and measureable variables, parameters that have reached critical values can be indicated, as well as the extent to which they enter the risk zone.

Garza-Reyes et al. (2018) showed the risk occurence by using colours: Green - Little impact or no risk; Yellow - Low or moderate risk; Red High impact and risk; and Grey - Risk unknown or incomplete. In order to document errors, deviations and defects, a descriptive analysis using the $5 \mathrm{~S}$ tool came in handy.

This tool helps us find the spots where the gap occurs, evidented errors and occurence frequency. 
The focus is on the workplace standardization, i.e. potential risks ought to be removed through implementing certain procedures and control of the input-output technological documentation.

The action plan involves describing the area of activity and the steps needed to bridge the gap, as in Table 4. Within this plan, all the necessary activities should be defined, in order to ensure a complete harmony of process elements (Marra et al., 2018). The action plan includes: (1) process, (2) process step, (3) current results, (4) desired results, (5) action, (6) target date. According to Cheng and Musaphir (1996), there is a great concern among managers about implementing the action plan in the production strategy, which also includes measuring performances, decision making and managing styles.

Table 2: Layout of current and future status reports

\begin{tabular}{|l|c|c|c|}
\hline Department: & $\begin{array}{c}\text { Gaps } \\
\text { (or potential risks) }\end{array}$ & $\begin{array}{c}\text { Required efforts to solve } \\
\text { or bridge the gaps }\end{array}$ \\
\hline No. & Operation & Activity & Future situation \\
\hline \multicolumn{2}{|c|}{ Present situation } & & \\
\hline & & &
\end{tabular}

Table 3: Checklist in GAP Analysis

\begin{tabular}{|c|c|c|c|c|}
\hline No. & Risky event & Description & Conditional variables & Note \\
\hline & $(1)$ & $(2)$ & $(4)$ \\
\hline
\end{tabular}

Table 4: Action Plan in GAP Analysis

\begin{tabular}{|c|c|c|c|c|c|c|}
\hline No. & $\begin{array}{c}\text { Process } \\
\text { (1) }\end{array}$ & $\begin{array}{c}\text { Process step } \\
\text { (2) }\end{array}$ & $\begin{array}{c}\text { Current results } \\
\text { (3) }\end{array}$ & $\begin{array}{c}\text { Desired results } \\
\text { (4) }\end{array}$ & $\begin{array}{c}\text { Action } \\
\text { (5) }\end{array}$ & $\begin{array}{c}\text { Target date } \\
\text { (6) }\end{array}$ \\
\hline & & & & & & \\
\hline
\end{tabular}

\section{$5 S$ tool}

Lean production means improving the production flow or work continuity through workplace control. Lean concept is directed towards finding real activities, putting things in the right place at the right time, in order to achieve a perfect work flow with minimum waste (Dora et al., 2016).

Taj (2005) emphasizes two important aspects in considering lean production: human and technological (non-human). The technological aspect of lean production involves projecting the production process (planning, inventory availability, supply chain). On the other hand, the human aspect includes projecting the organization (organizational structure, safety and work division, organizational capacity and training).

For the lean production specifically, the $5 \mathrm{~S}$ tool turned out to be very useful. Esain et al. (2008) defined the $5 \mathrm{~S}$ tool as a structural method for accelerating operational changes and they focused on discipline and control at the workplace, in order to minimize potential risks.

Applying the $5 \mathrm{~S}$ tool within the enterprise implies a systematic approach, i.e. team work with the participation of all employees. The implementation of this tool encourages employees to improve their working conditions and helps them reduce waste, unexpected deadlocks and unnecessary inventory (Gapp et al., 2008). Chapman (2005) emphasizes that the $5 \mathrm{~S}$ tool is very important for the production system and managing its operations, while it also requires less human effort, space, capital and time for producing, with fewer mistakes.

The name $5 \mathrm{~S}$ derives from the first letters of Japanese words: Seiri, Seiton, Seiso, Seiketsu and Shitskue.

1. Seiri (Sort - sorting) implies eliminating unnecessary items in the workplace, i.e. removing waste, unnecessary machines and tools, as well as damaged tools (Harrington, 2000).

2. Seiton (Straighten - put everything to its place) means that all things should be in exactly defined places, so they are easily accesible for using, which eliminates the need for searching. Seiton also implies efficient storing and the activities that should be carried on for a longer periods of time (Peterson and Smith, 2001).

3. Seiso (Shine - cleaning) focuses on cleaning, which represents a type of inspection used to 
identify unexpected states that could possibly jeopardize the quality or cause the machine to break. Also, cleaning eliminates the waste (Osada, 1993).

4. Seiketsu (Standardize - to standardize). While the previous three elements represent a routine, this one focuses on their visual management. Standardization is about procedures and actions which are necessary in order to keep the workplace tidy and clean, tools and raw materials at the fingertips of employees, as well as to simply notice all the items that are redundant (Michalska \& Szewieczek, 2007).

5. Shitsuke (Sustain - sustainability, discipline) implies the possibility of creating a workplace with great work habits and discipline.

\section{METHODOLOGY}

In this case study, there is an example of realizing and assemblying the CPT of the domestic manufacturer ICTM-CMT. The period of monitoring and evidenting mistakes, in the process of production and transmitter assembly, lasted from March 2016 to December 2018.

On that occasion, errors (or potential risks) were grouped according to modules. CPT is consisted of two modules: 1.) measuring chambers (where the sensor is placed) with the transitional fixing element, and 2.) electronics box with the circuit. In the Figure 2, a photograpfic display of the realized CPT is given.

According to Gershenson et al. (2004), it is necessary that all the product models can be disassembled and that they are projected for reusing and recycling. In the Table 5, a display of the number of elements and necessary technological processes in the CPT realization is given.

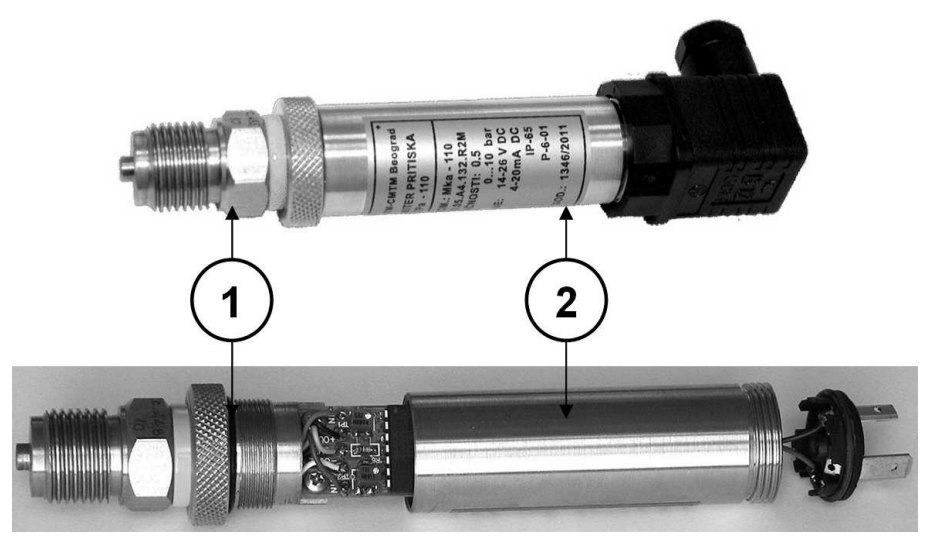

Figure 2: Realized CPT through modules:

(1) measurement cell with mechanical coupling fixture; 2) enclosure)

Table 5: Summary of required elements and technological operations in the implementation of the CPT module

\begin{tabular}{|c|l|c|l|}
\hline No. & \multicolumn{1}{|c|}{ Module name } & $\begin{array}{c}\text { Number of } \\
\text { components }\end{array}$ & \multicolumn{1}{c|}{ Technological operations } \\
\hline 1. & $\begin{array}{l}\text { Measurement cell (containing } \\
\text { the sensing element) with } \\
\text { mechanical coupling fixture }\end{array}$ & 6 & $\begin{array}{l}\text { - Element processing according to technical and } \\
\text { technological documentation } \\
- \text { Vacuuming and filling the cell with oil } \\
\text { - Welding cell elements } \\
\text { - Soldering electronic components }\end{array}$ \\
\hline 2. & $\begin{array}{l}\text { Enclosure (containing the } \\
\text { electronics and the terminal } \\
\text { block box) }\end{array}$ & 5 & $\begin{array}{l}\text { - Element processing according to technical and } \\
\text { technological documentation } \\
- \text { Using external technologies } \\
\text { - Implementing the electronic circuit }\end{array}$ \\
\hline
\end{tabular}

While designing the product, it is important to consider the system modularity, through defining plans, proper allocation of operations and management (Baldwin and Clark, 2000). In general, modular product design has several advantages: ease of assembly and maintenance 
(Holtta-Otto and de Veck 2007), as well as simple adaptability of architecture to new changes (Engel et al., 2017).

This work tries to analyze the gap in a complex design of the production and CPT assembly process. By introducing the $5 \mathrm{~S}$ tool, complexity issues in assemblying the module at the workplace are being analyzed. Products having more components represent a complex structure in terms of designing, development and connecting.

\section{EXPERIMENTAL WORK}

GAP analysis has been carried out on the example of CPT. It was stated that there are certain irregularities and that the gap has occured in the process of making and assemblying the CPT. Solving of the encountered issues has been carried out through five steps of the GAP analysis and implemetation of the $5 \mathrm{~S}$ tool at the workplace level. The first step is closely connected with the production department. As a solution, a report about current and future state was given, as in Table 6.

Table 6: The report on the current and future situtation of the CPT

\begin{tabular}{|c|c|c|c|c|}
\hline \multicolumn{3}{|c|}{ Department: Transmitter production } & \multirow{2}{*}{ Gaps or potential risks } & \multirow{2}{*}{$\begin{array}{l}\text { The required efforts to solve } \\
\text { or bridge the gaps }\end{array}$} \\
\hline No. & Operation & Activity & & \\
\hline \multirow{2}{*}{\multicolumn{5}{|c|}{$\begin{array}{l}\text { Present situation } \\
\text { I - Measurement cell with mechanical coupling fixture }\end{array}$}} \\
\hline & & & & \\
\hline 1 & $\begin{array}{l}\text { Production of } \\
\text { element }\end{array}$ & $\begin{array}{l}\text { Machine } \\
\text { production of } \\
\text { elements }\end{array}$ & $\begin{array}{l}\text { Use of outdated technologies can } \\
\text { lead to poor quality of finished } \\
\text { pieces. Inspection parameter is } \\
\text { not regular. }\end{array}$ & $\begin{array}{l}\text { Improve the final inspection of } \\
\text { element processing. Provide } \\
\text { funds for the purchase of new } \\
\text { generation machines or repaired } \\
\text { machines. }\end{array}$ \\
\hline 2 & $\begin{array}{l}\text { Assembling of } \\
\text { elements }\end{array}$ & $\begin{array}{l}\text { Joining and } \\
\text { inspection }\end{array}$ & $\begin{array}{l}\text { Errors occur in the coupling of } \\
\text { the chip (with wire terminals) and } \\
\text { other mechanical parts of the } \\
\text { measuring chamber. }\end{array}$ & $\begin{array}{l}\text { Improve final inspection when } \\
\text { joining the elements. }\end{array}$ \\
\hline 3 & Welded joint & Welded joint test & $\begin{array}{l}\text { The quality and appearance of the } \\
\text { welded joint depends on the } \\
\text { machining of the elements and } \\
\text { the choice of welding parameters. } \\
\text { Inadequate selection of welding } \\
\text { parameters can cause the circular } \\
\text { metal membrane to burn. }\end{array}$ & $\begin{array}{l}\text { Inspect the prepared surfaces } \\
\text { and welding parameters } \\
\text { according to the prescribed } \\
\text { technology (visual inspection. } \\
\text { Perform continuous inspection } \\
\text { of the welded joint visually and } \\
\text { via helium detectors. }\end{array}$ \\
\hline 4 & Oil filling & $\begin{array}{l}\text { Machine } \\
\text { preparation }\end{array}$ & $\begin{array}{l}\text { Poor quality of machine } \\
\text { preparation and final processing } \\
\text { of elements. }\end{array}$ & $\begin{array}{l}\text { Improve the final inspection of } \\
\text { element processing. }\end{array}$ \\
\hline 5 & $\begin{array}{l}\text { Transitional } \\
\text { piece }\end{array}$ & $\begin{array}{l}\text { Machine } \\
\text { production of } \\
\text { elements }\end{array}$ & $\begin{array}{l}\text { Connects the measuring chamber } \\
\text { to the transmitter electronics box. } \\
\text { Error occur at machine } \\
\text { processing. }\end{array}$ & $\begin{array}{l}\text { Improve final inspection when } \\
\text { joining elements. }\end{array}$ \\
\hline \multicolumn{5}{|c|}{ II - Enclosure } \\
\hline 1 & $\begin{array}{l}\text { Box and } \\
\text { electronics }\end{array}$ & $\begin{array}{l}\text { Connecting and } \\
\text { installing of } \\
\text { electrical } \\
\text { components }\end{array}$ & $\begin{array}{l}\text { Errors occur at machine } \\
\text { processing. For electronic } \\
\text { assembly, errors occur when } \\
\text { assembling and soldering } \\
\text { components on printed circuit } \\
\text { boards, as well as during } \\
\text { assembly. } \\
\end{array}$ & $\begin{array}{l}\text { Improve and enhance the final } \\
\text { inspection of machining } \\
\text { elements. Also improve the way } \\
\text { electronic components are } \\
\text { assembled on the box. }\end{array}$ \\
\hline 2 & $\begin{array}{l}\text { Plasticizing the } \\
\text { box }\end{array}$ & $\begin{array}{l}\text { Technology on } \\
\text { the other side (or } \\
\text { service) }\end{array}$ & $\begin{array}{l}\text { Surface protection technology, } \\
\text { which is not under the control of } \\
\text { the organization. }\end{array}$ & $\begin{array}{l}\text { Provide visual inspection of the } \\
\text { received elements. }\end{array}$ \\
\hline 3 & $\begin{array}{l}\text { Element } \\
\text { assemblying }\end{array}$ & Final inspection & $\begin{array}{l}\text { Errors occur due to incautious } \\
\text { assembly and after checking } \\
\text { meteorological parameters of the } \\
\text { finished product. }\end{array}$ & $\begin{array}{l}\text { Provide additional staff training. } \\
\text { Carry out the process of } \\
\text { receiving, controlling parameters } \\
\text { and storing the finished product. }\end{array}$ \\
\hline
\end{tabular}


The second step, pointing out at specific areas to be improved, was defined in the first step. Accordingly, the production process department has been considered (broader concept), more precisely, assemblying parts and components, as well as final control checks of end products (narrower concept).

The third step, which gives a perception of the future state, i.e. defines future enterprise goals in order to bridge the gap. Furthermore, the fourth step is very important, as it discovers current irregularities, mistakes, flaws and deviations from the desired values.

In this regard, the $5 \mathrm{~S}$ tool turned out to be useful for discovering irregularities in the production process. In the Table 7, display of error classification and their frequency during situation monitoring has been given.

After the 5S analysis of selecting flaws in realization of the CPT, preparation of the report began, as a starting point for identifying potential risky spots. In the Table 9, a control list is shown.

In the last step of the GAP analysis, an action plan for the implementation of possible solutions is made, in order to remove oversights between present and future status. In the Table 10, there is an action plan for the CPT module manufacturing and assemblying process.

Table 9: Checklist in the manufacturing and assembly process of CPT modules

\begin{tabular}{|c|l|l|c|c|}
\hline No. & \multicolumn{1}{|c|}{$\begin{array}{c}\text { Risky event } \\
(\mathbf{1})\end{array}$} & $\begin{array}{c}\text { Description of risk event } \\
(\mathbf{2})\end{array}$ & $\begin{array}{c}\text { Conditional variables } \\
(\mathbf{3})\end{array}$ & $\begin{array}{c}\text { Note } \\
(\mathbf{4})\end{array}$ \\
\hline 1 & Production of elements & Machining of elements & 22 & Inspection \\
\hline 2 & Welded joint & Welded joint test & 11 & Joining Inspection \\
\hline 3 & Box and electronics & $\begin{array}{l}\text { Joining and installing of } \\
\text { electrical components }\end{array}$ & 20 & Processing Inspection \\
\hline
\end{tabular}

Table 10: Action Plan in the manufacturing and assembly process of CPT modules

\begin{tabular}{|c|c|c|c|c|c|c|}
\hline No. & $\begin{array}{l}\text { Process } \\
\text { (1) }\end{array}$ & $\begin{array}{l}\text { Process step } \\
\text { (2) }\end{array}$ & $\begin{array}{l}\text { Current } \\
\text { results } \\
\text { (4) }\end{array}$ & $\begin{array}{l}\text { Desired } \\
\text { results } \\
(5)\end{array}$ & $\begin{array}{c}\text { Action } \\
\text { (6) }\end{array}$ & $\begin{array}{l}\text { Target date } \\
\text { (7) }\end{array}$ \\
\hline 1 & $\begin{array}{l}\text { Element } \\
\text { production }\end{array}$ & $\begin{array}{l}\text { Machine } \\
\text { element } \\
\text { production }\end{array}$ & $\begin{array}{c}\text { Improve } \\
\text { control }\end{array}$ & $\begin{array}{c}\text { Remove } \\
\text { irregularities }\end{array}$ & $\begin{array}{l}\text { Review } \\
\text { processing } \\
\text { technology }\end{array}$ & Up to 2 weeks \\
\hline 2 & $\begin{array}{c}\text { Element } \\
\text { assembly }\end{array}$ & $\begin{array}{l}\text { Merging and } \\
\text { control }\end{array}$ & $\begin{array}{c}\text { Improve } \\
\text { control }\end{array}$ & $\begin{array}{c}\text { Remove } \\
\text { irregularities }\end{array}$ & Staff training & One week \\
\hline 3 & Welded joint & $\begin{array}{l}\text { Welded joint } \\
\text { testing }\end{array}$ & $\begin{array}{l}\text { Improve } \\
\text { merging and } \\
\text { control }\end{array}$ & $\begin{array}{c}\text { Remove } \\
\text { irregularities }\end{array}$ & $\begin{array}{l}\text { Review } \\
\text { processing } \\
\text { technology }\end{array}$ & Up to 2 weeks \\
\hline 4 & Oil filling & $\begin{array}{l}\text { Machine } \\
\text { preparation }\end{array}$ & $\begin{array}{l}\text { Improve } \\
\text { processing }\end{array}$ & $\begin{array}{c}\text { Remove } \\
\text { irregularities }\end{array}$ & $\begin{array}{l}\text { Review } \\
\text { processing } \\
\text { technology }\end{array}$ & $\begin{array}{l}\text { Up to one } \\
\text { month }\end{array}$ \\
\hline 5 & $\begin{array}{l}\text { Transitional } \\
\text { piece }\end{array}$ & $\begin{array}{l}\text { Machine } \\
\text { production of } \\
\text { element }\end{array}$ & $\begin{array}{c}\text { Improve } \\
\text { control }\end{array}$ & $\begin{array}{c}\text { Remove } \\
\text { irregularities }\end{array}$ & $\begin{array}{c}\text { Review } \\
\text { existing } \\
\text { technology }\end{array}$ & One week \\
\hline 6 & $\begin{array}{l}\text { Box and } \\
\text { electronics }\end{array}$ & $\begin{array}{l}\text { Merging and } \\
\text { controlling } \\
\text { electrical } \\
\text { components }\end{array}$ & $\begin{array}{c}\text { Imrove } \\
\text { processing and } \\
\text { control }\end{array}$ & $\begin{array}{c}\text { Remove } \\
\text { irregularities }\end{array}$ & $\begin{array}{c}\text { Review } \\
\text { processing } \\
\text { technology } \\
+ \\
\text { Staff training }\end{array}$ & $\begin{array}{l}\text { Up to one } \\
\text { month }\end{array}$ \\
\hline 7 & $\begin{array}{c}\text { Box } \\
\text { plastification }\end{array}$ & $\begin{array}{l}\text { Other party } \\
\text { technology (or } \\
\text { service) }\end{array}$ & $\begin{array}{c}\text { Improve } \\
\text { control }\end{array}$ & $\begin{array}{c}\text { Remove } \\
\text { irregularities }\end{array}$ & Staff training & One week \\
\hline 8 & $\begin{array}{c}\text { Element } \\
\text { assemblying }\end{array}$ & Final control & $\begin{array}{c}\text { Improve } \\
\text { control }\end{array}$ & $\begin{array}{c}\text { Remove } \\
\text { irregularities }\end{array}$ & Staff training & One week \\
\hline
\end{tabular}

Application and realization of the $5 \mathrm{~S}$ tool in this work is focused on the realization process of the
CPT. The 5S tool starts from the workplace, where the noticed waste is being removed. Everything is 
planned to detail, so that the omissions (gaps) are not to be repeated later on.

Workplace together with additional materials, tools and machines has been analyzed. The final piece that came out of the workshop is first being washed and dried, followed by visual control and additional polishing/drilling/cutting of the washed piece.
Table 11 shows methodoligical approach of these tools application. All elements are analyzed here according to the following criteria: 1) significance level - (the existing level and what activities have been taken?), 2) Note (Why is it important?) and 3) Problem solution (How to end problems and how to achieve the wished results?).

Table 11: Applications of 5S tools in receiving finished elements from a workshop

\begin{tabular}{|c|c|c|c|c|}
\hline Element & $\begin{array}{c}\text { Level of } \\
\text { significance }\end{array}$ & $\begin{array}{l}\text { Risk elimination } \\
\text { activities }\end{array}$ & $\begin{array}{l}\text { Troubleshooting / } \\
\text { Problem solving }\end{array}$ & Remark \\
\hline ڤ̆ & $\begin{array}{l}\text { Remove any } \\
\text { excess and } \\
\text { irrelevant } \\
\text { elements }\end{array}$ & $\begin{array}{l}\text { Mark critical points } \\
\text { (red or risk zone). } \\
\text { Mark the green zone } \\
\text { after eliminating the } \\
\text { risk. }\end{array}$ & $\begin{array}{l}\text { Unnecessary items are } \\
\text { postponded or discarded. It } \\
\text { reduces the waste of time } \\
\text { looking for assets and } \\
\text { parts. }\end{array}$ & $\begin{array}{l}\text { Workplace productivity } \\
\text { and quality are visible. } \\
\text { Space, time, energy and } \\
\text { money are better } \\
\text { utilized. }\end{array}$ \\
\hline 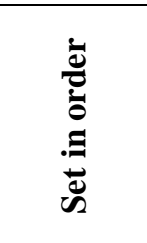 & $\begin{array}{l}\text { Place objects, } \\
\text { machines and } \\
\text { tools in the right } \\
\text { place. }\end{array}$ & $\begin{array}{l}\text { After use, all the } \\
\text { mentioned elements } \\
\text { must be returned in } \\
\text { order to avoid any risk. } \\
\text { Easy to access and } \\
\text { manage. }\end{array}$ & $\begin{array}{l}\text { Prevents inventory loss, } \\
\text { separate the correct from } \\
\text { the defective products. } \\
\text { Manipulating elements in } \\
\text { the workplace is better. }\end{array}$ & $\begin{array}{l}\text { Remaining production, } \\
\text { elements that have no } \\
\text { usable value and } \\
\text { elements that are not } \\
\text { part of the production } \\
\text { program are eliminated. }\end{array}$ \\
\hline מ. & $\begin{array}{l}\text { The workplace } \\
\text { should be kept } \\
\text { tidy and clean }\end{array}$ & $\begin{array}{l}\text { Mandatory inspection } \\
\text { of workplace after each } \\
\text { activity performed. }\end{array}$ & $\begin{array}{l}\text { Mark critical areas on } \\
\text { which there could be } \\
\text { undesirable } \\
\text { occurrences/risks: dust, } \\
\text { contaminated zone, water } \\
\text { and oil leaks, inaccessible } \\
\text { access to machinery. }\end{array}$ & $\begin{array}{l}\text { Tidy, clean, bright and } \\
\text { controlled workplace } \\
\text { provides better } \\
\text { incentives for work. }\end{array}$ \\
\hline 芯 & $\begin{array}{l}\text { Procedures for the } \\
\text { operation, } \\
\text { exploitation and } \\
\text { maintenance of } \\
\text { tools, equipment } \\
\text { and machines are } \\
\text { standardized. }\end{array}$ & $\begin{array}{l}\text { Standardize all } \\
\text { activities at workplace. } \\
\text { Define and write } \\
\text { procedures. }\end{array}$ & $\begin{array}{l}\text { The work surfaces must be } \\
\text { clean, tidy and equipped } \\
\text { with the most necessary } \\
\text { materials, tools and } \\
\text { machines. } \\
\text { Procedures must be } \\
\text { followed. }\end{array}$ & $\begin{array}{l}\text { Elements quality, if any, } \\
\text { are taken as the starting } \\
\text { point. }\end{array}$ \\
\hline 笣 & $\begin{array}{l}\text { Employees need } \\
\text { to build up the } \\
\text { habit of } \\
\text { maintaining the } \\
\text { workplace } \\
\text { properly }\end{array}$ & $\begin{array}{l}\text { Continuous } \\
\text { improvement of } \\
\text { working activities. }\end{array}$ & $\begin{array}{l}\text { Introduce discipline in the } \\
\text { workplace by: preventing } \\
\text { the accumulation of } \\
\text { unnecessary items, } \\
\text { returning tools and } \\
\text { accessories to a defined } \\
\text { location, cleaning work } \\
\text { surfaces and dirty tools, } \\
\text { monitoring machines } \\
\text { during and after work. }\end{array}$ & $\begin{array}{l}\text { Follow the prescribed } \\
\text { procedures with } \\
\text { continuous training of } \\
\text { employees in the } \\
\text { workplace. }\end{array}$ \\
\hline
\end{tabular}

According to Klarin et al. (2003), supplying the workplace with adequate workload, as well as its relocation, has to be done completely and on time. At the workplace, there should be a suitable staff, but also: machines, devices, installations, tools and equipment, supplies, water, electric energy and means of protection.
In case they determine errors, employees must take action immediately and quickly, in order to prevent production delays. Control becomes a crucial part in the manufacturing process, carried out by the employees working in production: from controlling parts and systems, to final control of the finished product. 
M. Vorkapic $\quad 5$ S Elements as steps to bridge the gap in

et al. transmitter manufacturing process

\section{DISCUSION}

Modular design in transmitter implementation is a general concept that describes the extent to which system components can be independent. Reassembly of the module within the system, while adding new ones, enables realization of new products, as well as introducing potential risks. In the example of CPT realization, it has been stated that losses exist.

According to the report and conducted action plan, it can be claimed that the main causes of risk occurence in the GAP analysis are the following:
1. Human factor. Issues are evident, and one of the most influential ones are: poor control at the workplace, poor training and incompetency of employees for the predicted position.

2. Processing technology, which implies technologically outdated machines. That leads to huge complications in the sense of honouring tolerancies defined by technical documentation.

These two gaps (risks) must be systematically removed, so the production process could go on undisturbedly. Hence, the Figure 3 shows the algorithm of implementing the $5 \mathrm{~S}$ tool in the GAP analysis, during CPT realization.

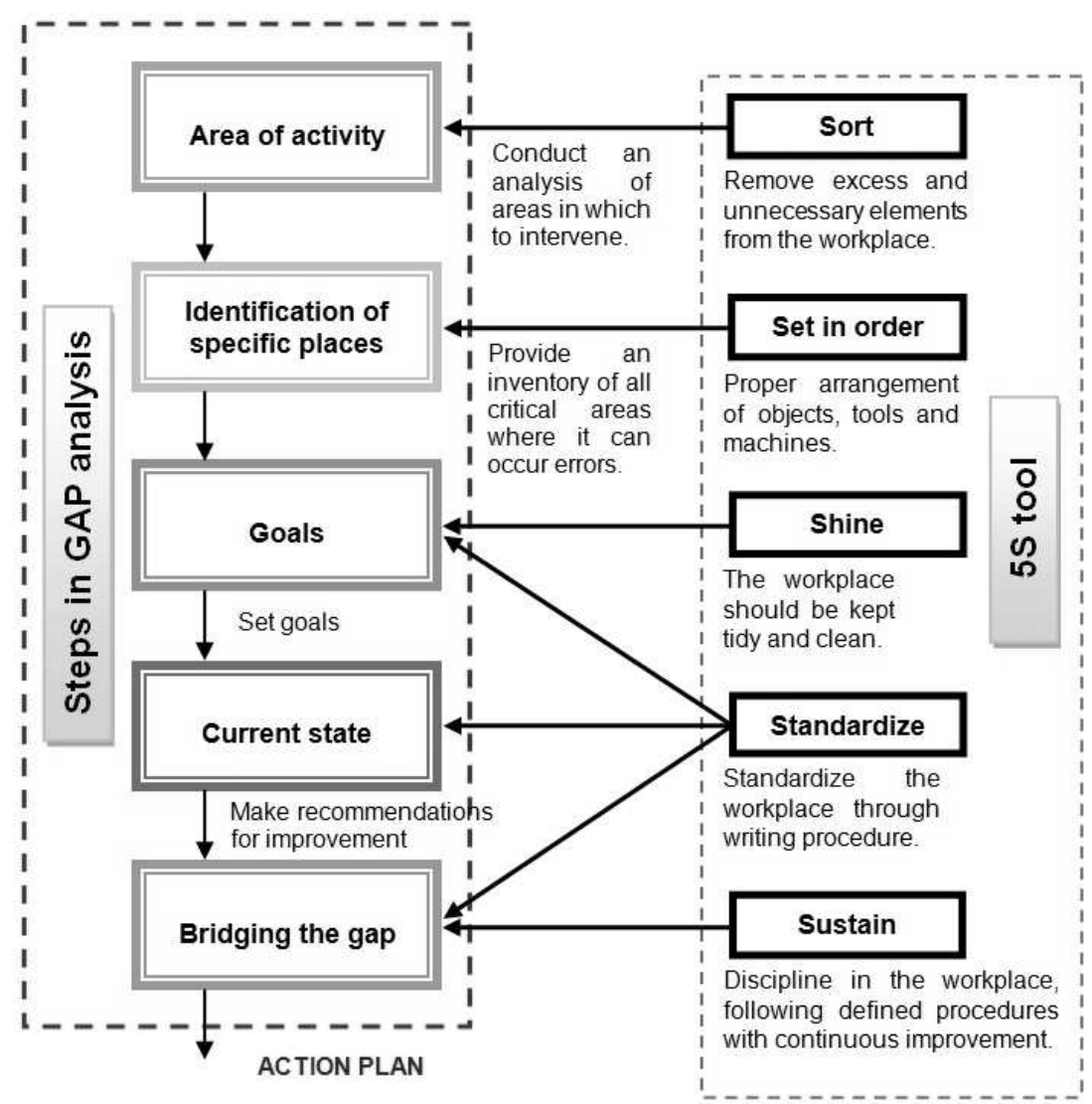

Figure 3: 5S tools implementation in GAP analysis

In realizing individual steps of the GAP analysis, the $5 \mathrm{~S}$ tool has turned out to be very efficient on the workplace level. Solving these steps causes creation of an action plan, which includes a complete $5 \mathrm{~S}$ tool, with the final goal to discover and remove all the errors on time. Each step of the $5 \mathrm{~S}$ tool examines in a timely manner the set step of GAP analysis in bridging the gap. Therefore, the following connections are evidential:

1. Area of activity - Sort. GAP analysis begins by considering interesting activities or processes from the point of view of error occurence on the workplace level. According to the definition, the Sort tool points out the existence of the risk zone in the workplace, which should be removed or recombined.

2. Identification of specific places - Set in order. In this step, a list of all critical locations is made. Set in order encourages this activity by reordering and putting things back to their proper place.

3. Goals, - Shine, Standardize. Setting goals for bridging the gap is followed by activities that make the workplace clean and standardized 
according to defined tasks. Procedures regarding the workplace must be respected.

4. Current state - Standardize. The current state analysis cannot remove potential risks unless a standardization of procedures and activities at the workplace is carried out through defined actions. In this step, recommendations for improving workplace activities are given.

5. Bridging the gap - Standardize, Sustain. Making an action plan with the goal of bridging the gap requires complete standardization of activities and processes with defined procedures and setting discipline at the workplace.

\section{CONCLUSION}

Combining 5S tool through GAP analysis enables the assessment of all business and process activities both at the workplace and throughout the organization. Finding critical points as sources of potential risks greatly accelerates GAP analysis of the first $5 \mathrm{~S}$ elements analyzed.

With the use of the $5 \mathrm{~S}$ tools, key points in the manufacturing process have emerged that indicate major failures characterized as existing errors in the further implementation of the CPT. However, their frequent appearance indicates that they can become a risk, as they can disrupt the production process and final assembly. Potential risks arise if these errors are not eliminated. GAP analysis allows us to detect the association of potential risk factors that lead to deviations from the planned quality goals and constantly controlled manufacturing process.

All of this indicates that the negative effects can be minimized by the use of $5 \mathrm{~S}$ tools, thus maximizing the opportunities for improvement. Gaps that occur at the level of processing technology are certainly in a functional relation with the workplace. Therefore, in the quality control of some mechanical parts, as well as electrical modules, it is necessary to pay more attention to the workplace. By eliminating these errors in the manufacturing process, a reduction of failures (risks), and an improved level of quality production can be accomplished.

\section{ACKNOWLEDGEMENT}

This work is a part of current projects TR-32008 and TR-35035 funded by Ministry of Education, Science and Technological Development of the Republic of Serbia.

\section{REFERENCES}

Awasthi, M. K., Sarsaiya, S., Wang, Q., Wang, M., Chen, H., Ren, X., Kumar, S., \& Zhang, Z. (2018). Mitigation of Global Warming Potential for Cleaner Composting. In Biosynthetic Technology and Environmental Challenges (pp. 271-305). Springer, Singapore.

Baldwin, C. Y., \& Clark, K. B. (2000). Design rules: The power of modularity. MIT press.

Chapman, C. D. (2005). Clean house with lean 5S. Quality progress, 38(6), 27-32.

Cheng, T. C. E., \& Musaphir, H. (1996). Theory and practice of manufacturing strategy. International Journal of Production Research, 34(5), 1243-1259.

Davis, R., Misra, S., \& Van Auken, S. (2002). A gap analysis approach to marketing curriculum assessment: A study of skills and knowledge. Journal of Marketing Education, 24(3), 218-224.

Dora, M., Kumar, M., \& Gellynck, X. (2016). Determinants and barriers to lean implementation in food-processing SMEs-a multiple case analysis. Production Planning \& Control, 27(1), 1-23.

Edmund, H. C., \& Patricia, S. S. (1997). Implementing risk management on software intensive projects. IEEE Softw, 83-89.

Engel, A., Browning, T. R., \& Reich, Y. (2017). Designing products for adaptability: insights from four industrial cases. Decision Sciences, 48(5), 875917.

Esain, A., Williams, S., \& Massey, L. (2008). Combining planned and emergent change in a healthcare lean transformation. Public Money and Management, 28(1), 21-26.

Garza-Reyes, J. A., Romero, J. T., Govindan, K., Cherrafi, A., \& Ramanathan, U. (2018). A PDCAbased approach to Environmental Value Stream Mapping (E-VSM). Journal of Cleaner Production, 180, 335-348.

Gapp, R., Fisher, R., \& Kobayashi, K. (2008). Implementing $5 \mathrm{~S}$ within a Japanese context: an integrated management system. Management Decision, 46(4), 565-579.

Gershenson, J. K., Prasad, G. J., \& Zhang, Y. (2004). Product modularity: measures and design methods. Journal of engineering Design, 15(1), 33-51.

Harrington, H.J. (2000) Business Process Improvement: The Breakthrough Strategy for Total Quality, Productivity, and Competitiveness, McGraw-Hill Inc., New York

Hölttä-Otto, K., \& De Weck, O. (2007). Degree of modularity in engineering systems and products with technical and business constraints. Concurrent Engineering, 15(2), 113-126.

Klarin, M. M., Cvijanović, J. M., Lazić, J. M., \& Spasojević-Brkić, V. (2003). Istraživanje raspoloživosti proizvodnih kapaciteta $\mathrm{u}$ metalopreradi. Industrija, 31(3-4), 1-6. 
Kliem, R. L. (2000). Risk management for business process reengineering projects. Information systems management, 17(4), 71-73.

Marra, M., Di Biccari, C., Lazoi, M., \& Corallo, A. (2018). A Gap Analysis Methodology for Product Lifecycle Management Assessment. IEEE Transactions on Engineering Management, 65(1), 155-167.

Michalska, J. (2006). Quality costs in the production process. Journal of Achievements in Materials and Manufacturing Engineering, 17(1-2), 425-428.

Michalska, J., \& Szewieczek, D. (2007). The 5S methodology as a tool for improving the organization. Journal of Achievements in Materials and Manufacturing Engineering, 24(2), 211-214.

Miller, R., \& Lessard, D. (2001). Understanding and managing risks in large engineering projects. International Journal of Project Management, 19(8), 437-443

Mogos, M. F., Fredriksson, A., \& Alfnes, E. (2019). A production transfer procedure based on risk management principles. Journal of Global Operations and Strategic Sourcing, 12(1), 103-150.

Osada Takashi "The 5S's: five keys to a total quality environment" Asian Productivity Organization, 1993
Peterson, J. and Smith, R. (2001) The 5S Pocket Guide, Quality Resources, New York.

Taj, S. (2005). Applying lean assessment tools in Chinese hi-tech industries. Management Decision, 43(4), 628-643.

Tilley, P.A., McFallen, S.L., and Tucker, S.N. (2000). "Design and Documentation Quality and Its Impact on the Construction Process." AISC - IEAust Special Issue Steel Construction, 34(4), 7-14.

Tsai, W. H., Hsu, W., \& Chou, W. C. (2011). A gap analysis model for improving airport service quality. Total Quality Management \& Business Excellence, 22(10), 1025-1040.

Vorkapić, M., Ćoćkalo, D., Spasojević Brkić, V., Đorđević, D., \& Brkić, A. (2019). GAP Analysis and Risk Occurence on the Example of Pressure Transmitter's Production Processes. Journal of Applied Engineering Science, 17(4), 590 - 598. doi: 10.5937/jaes17-23443

Williams, T. (1995). A classified bibliography of recent research relating to project risk management. European journal of operational research, 85(1), 18-38.

\title{
5S ELEMENTI KAO KORACI ZA PREMOŠĆIANJE PROCEPA U PROCESU PROZVODNJE TRANSMITERA
}

\begin{abstract}
U ovom radu, analizirani su GAP analiza i $5 S$ alat na primeru realizacije malogabaritnog transmitera pritiska. GAP analiza, u kombinaciji sa 5S alatom, može kvalitetno ukazuje na kritične tačke u procesu proizvodnje, sklapanja i kontrole gotovog transitera. Postojeće greške dovode do pojave mogućih rizika u realizaciji proizvodnih procesa, od ulaza repromaterijala do sklapanja gotovog proizvoda. Aaliza rizika, omogućava organizaciji da preuzme određene korake u prihvatanju ili smanjenju njegovog uticaja. $5 \mathrm{~S}$ alat u GAP analizi pomaže da se rizična mesta srede i dovedu u funkcionalno stanje, sa što manje gubitaka (otpada). Zbog eliminacije postojećih greškaka, u radu su detaljno opisani glavni koraci GAP analize. Date su smernice kako da se unapredi proces proizvodnje na radnom mestu kroz određena poboljšanja primenom svih $5 \mathrm{~S}$ elemenata. Prema sprovedenom akcionom planu konstatovano je da su glavni uzročnici pojave rizika u GAP analizi sledeći: ljudski faktor i tehnologije obrade. Ljudski faktor je okarakterisan slabom kontrolom na radnom mestu (ne postoji disciplina), slabom obukom i nekompetentnošću zaposlenih za propsano radno mesto. Tehnologija obrade podrazumeva tehnološki zastarele mašine i odstupanja mera i tolerancija od propisanih vrednosti.
\end{abstract}

Ključne reči: GAP analyza; 5S; Rizik; Proces proizvodnje; Transmiter; Unapređenje. 